\title{
Hypocapnia-induced contraction of porcine airway smooth muscle
}

\author{
K.S. Lindeman, T.L. Croxton, B. Lande, C.A. Hirshman
}

\begin{abstract}
Hypocapnia-induced contraction of porcine airway smooth muscle. K.S. Lindeman, T.L. Croxton, B. Lande, C.A. Hirshman. (ERS Journals Ltd 1998.

ABSTRACT: Hypocapnia constricts peripheral airways in vivo. This study investigated the role of airway smooth muscle in this phenomenon and the mechanism of hypocapnia-induced contraction in vitro.

Isometric tension, intracellular $\mathbf{p H}\left(\mathrm{pH}_{\mathrm{i}}\right)$ and intracellular free calcium concentration $\left(\left[\mathrm{Ca}^{2+}\right]_{\mathrm{i}}\right)$ were measured in porcine airway smooth muscles suspended in organ baths in the presence of $5 \%$ or $0 \% \mathrm{CO}_{2}$.

In tracheal strips precontracted with carbachol, hypocapnic challenge $\left(0 \% \mathrm{CO}_{2}\right)$ produced increases in tension, $\mathrm{pH}_{\mathrm{i}}$, and $\left[\mathrm{Ca}^{2+}\right]_{\mathrm{i}}$. In bronchial rings or tracheal strips precontracted with carbachol, nifedipine administered between consecutive contractions attenuated responses to hypocapnia $(75 \pm 11 \%$ above carbachol-precontracted tension before nifedipine versus $39 \pm 9 \%$ after nifedipine, $n=7$ bronchial rings, $p<0.05$ ). Neither indomethacin $(5 \mu \mathrm{M})$, nordihydroguaiaretic acid $(10 \mu \mathrm{M})$ nor phenidone (10 $\mu \mathrm{M})$ significantly altered responses.

These data suggest that enhanced $\mathrm{Ca}^{2+}$ influx through voltage-dependent $\mathrm{Ca}^{2+}$ channels of airway smooth muscle cells is important in airway responses to hypocapnia. Eur Respir J 1998; 12: 1046-1052.
\end{abstract}

Hypocapnia increases human [1-4] and canine [5-10] airway resistance in vivo. In the canine lung periphery, this response is not altered by atropine but is reduced by nifedipine and verapamil [6, 7], and enhanced by BAY K8644 [11], suggesting that decreases in carbon dioxide tension $\left(\mathrm{PCO}_{2}\right)$ may cause airway smooth muscle contraction by a mechanism that involves voltage-dependent calcium channels in some airway cell types. However, the cell type(s) responsible for this response and details of the cellular pathway are not known.

Entry of extracellular calcium is important for airway smooth muscle contraction [12]. Airway smooth muscle cells contain L-type voltage-dependent calcium channels and current through these channels is increased by intracellular alkalosis [13]. However, it is not clear whether or not $\mathrm{pH}$ effects on $\mathrm{Ca}^{2+}$ channels in isolated myocytes are important in hypocapnia-induced airway constriction in vivo or in vitro. If $\mathrm{pH}$ modulation of voltage-dependent calcium channels in airway smooth muscle cells is important in hypocapnia-induced airway constriction, then 1) isolated airway smooth muscle should contract in vitro in response to decreases in $\left.\mathrm{PCO}_{2} ; 2\right)$ the contraction should be accompanied by increases in intracellular $\mathrm{pH}\left(\mathrm{pH}_{\mathrm{i}}\right)$ and increases in intracellular free $\mathrm{Ca}^{2+}$ concentration $\left(\left[\mathrm{Ca}^{2+}\right]_{\mathrm{i}}\right.$ ); and 3) the contraction should be inhibited by L-type calcium-channel antagonists, but should be unaffected by inhibition of the cyclo-oxygenase and leukotriene pathways (which might be activated by the effects of hypocapnia on the airway epithelium). To test these predictions, the effects of decreases in $\mathrm{PCO}_{2}$ were measured on resting tension, $\mathrm{pH}_{\mathrm{i}}$ and $\left[\mathrm{Ca}^{2+}\right]_{\mathrm{i}}$ in porcine airway smooth muscle and pharmacological modulation of in vitro hypocapnic tension responses was attempted.
Depts of Anesthesiology/Critical Care Medicine and Environmental Health Sciences, The Johns Hopkins University, Baltimore, USA.

Correspondence: K.S. Lindeman

Meyer 297A

The Johns Hopkins Hospital

600 N. Wolfe Street

Baltimore, MD 21287-7294

USA

Fax: 14109558978

Keywords: Airway smooth muscle, 27', 7'bis (2-carboxyethyl)-5(6)-carboxyfluorescein, calcium channels, fura-2, intracellular free calcium ions, intracellular $\mathrm{pH}$

Received: October 211997

Accepted after revision May 251998

Supported by National Institutes of Health, HL02417

\section{Methods}

\section{Tissue preparation}

Yorkshire-Hampshire pigs $(25-35 \mathrm{~kg}$ ) were sedated with ketamine hydrochloride $\left(30 \mathrm{mg} \cdot \mathrm{kg}^{-1}\right.$, i.m. $)$, anaesthetized with sodium pentobarbital $\left(20 \mathrm{mg} \cdot \mathrm{kg}^{-1}, i . v\right.$. $)$ and exsanguinated. The lungs and trachea were removed and immersed in Krebs-Henseleit solution containing (in $\mathrm{mM}$ ): $\mathrm{NaCl} 118$, $\mathrm{KCl}$ 4.7, $\mathrm{CaCl}_{2} 2.5, \mathrm{MgSO}_{4}$ 0.6, $\mathrm{KH}_{2} \mathrm{PO}_{4} 1.2, \mathrm{NaHCO}_{3}$ 20.9 and dextrose 11.1. Intraparenchymal bronchi, at least two branches distal to the carina, were dissected and sliced into rings 3-4 $\mathrm{mm}$ in diameter and 3-4 $\mathrm{mm}$ wide. Because a preliminary study had not demonstrated significant effects of epithelial removal on responses to changes in $\mathrm{CO}_{2}$ concentration [14], the epithelium was left intact. Tracheal smooth muscle strips were prepared by opening the trachea with a longitudinal ventral incision, removing the epithelium with forceps and cutting strips circumferentially ( $\sim 2 \mathrm{~mm}$ wide for tissue bath studies and $\sim 6 \mathrm{~mm}$ wide for fluorescence measurements of $\mathrm{pH}_{\mathrm{i}}$ and $\left[\mathrm{Ca}^{2+}\right]_{\mathrm{i}}$ ). The strips used for fluorescence measurements were carefully dissected free of connective tissue using a binocular microscope.

Bronchial rings and narrow tracheal strips were mounted in $10 \mathrm{~mL}$ glass organ chambers containing KrebsHenseleit solution bubbled initially with $95 \% \mathrm{O}_{2} / 5 \% \mathrm{CO}_{2}$

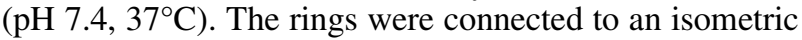
force transducer and suspended under $10 \mathrm{mN}$ or $30 \mathrm{mN}$ resting tension for rings and strips, respectively, the optimal tensions in these tissues $[15,16]$. The tissues were allowed to stabilize for approximately $1 \mathrm{~h}$ and were then 
contracted twice with carbamylcholine chloride (carbachol; $1 \mu \mathrm{M}$ or $0.1 \mu \mathrm{M}$ for rings or strips, respectively, corresponding to $\sim 50 \%$ effective does (ED50) for cholinergic agonists in these tissues $[17,18])$. Between the contractions, carbachol was washed from the chamber with fresh Krebs-Henseleit solution and the tension readjusted.

\section{Tissue bath protocols}

After equilibration, tissues were contracted to a stable plateau with carbachol $(1 \mu \mathrm{M}$ for rings and $0.1 \mu \mathrm{M}$ for tracheal strips) in $95 \% \mathrm{O}_{2} / 5 \% \mathrm{CO}_{2}$. A hypocapnic contraction was elicited by changing the gas bubbling through the chamber to $100 \% \mathrm{O}_{2}$. When tension reached a plateau, the gas was returned to $95 \% \mathrm{O}_{2} / 5 \% \mathrm{CO}_{2}$. The chambers were washed with fresh Krebs-Henseleit solution and allowed to equilibrate for an additional $30 \mathrm{~min}$. A second carbachol contraction and hypocapnic challenge was then performed. In some experiments, hypocapnic challenges were made by changing the gas mixture from $5 \% \mathrm{CO}_{2}$ in air to air without added $\mathrm{CO}_{2}$.

Pharmacological studies were performed with bronchial rings or tracheal strips. A first hypocapnic contraction was elicited as described above and, after the tissues were washed, either nothing, the $\mathrm{Ca}^{2+}$ channel blocker nifedipine ( 3 $\mu \mathrm{M}$ for bronchial rings and $0.1 \mu \mathrm{M}$ for tracheal strips) or its vehicle control (ethanol $0.02 \%$ final concentration), the cyclo-oxygenase inhibitor indomethacin $(5 \mu \mathrm{M})$ or one of the leukotriene inhibitors nordihydroguaiaretic acid (NDGA, $10 \mu \mathrm{M})$ or phenidone $(10 \mu \mathrm{M})$ was added to the chamber for $30 \mathrm{~min}$. A second carbachol contraction and hypocapnic challenge was then performed. Fourteen rings and seven strips from 11 animals did not receive pharmacological treatment between 11 consecutive hypocapnic challenges. Thirteen rings and six strips from 10 animals were treated with nifedipine, seven rings from seven animals received ethanol, five strips from three animals received isoproterenol and six rings from six animals were treated with each of the other agents.

\section{Fluorescence measurements of intracellular ions}

These experiments were performed using wide tracheal strips in a water-jacketed $40-\mathrm{mL}$ acrylic bath designed to allow illumination of approximately a $5 \mathrm{~mm}$ circular area of the tissue and measurement of epifluorescence from the same area. Baseline tension was adjusted to $\sim 25 \mathrm{mN}$, a value determined in preliminary experiments to be optimal for active force generation. The more extensive removal of connective tissue in this preparation probably accounts for the fact that the optimal baseline tension for these wide strips was no greater than that for the narrow strips described above. Tension and fluorescence intensities were recorded by a microcomputer which controlled the mechanical selection of filters in the incident light path. Emitted light passed through a fibreoptic cable to a separate filter and a photomultiplier tube. The KrebsHenseleit solution in the bath was maintained at $37 \pm 0.5^{\circ} \mathrm{C}$ and vigorously bubbled with either $95 \% \mathrm{O}_{2} / 5 \% \mathrm{CO}_{2}$ (control) or $100 \% \mathrm{O}_{2}$ (hypocapnia). Bath $\mathrm{pH}$ was monitored continuously using a combination electrode, the daily calibration at room temperature of which was adjusted to $37^{\circ} \mathrm{C}$ by applying the theoretical slope correction and defining the intercept with a single-point calibration at the higher temperature [19].

Tissues were loaded with 2',7'-bis(2-carboxyethyl)-5 (6)-carboxyfluorescein (BCECF) for measurement of $\mathrm{pH}_{\mathrm{i}}$ as previously described in detail [19]. In brief, the tissues were incubated with the acetoxymethyl ester of BCECF (BCECF-AM) for $45-75 \mathrm{~min}$ at $20-25^{\circ} \mathrm{C}$ and then washed and rewarmed to $37^{\circ} \mathrm{C}$. Fluorescence intensities were recorded at $540 \mathrm{~nm}$ during alternating illuminations with an excitation wavelength of $440 \mathrm{~nm}$ or $500 \mathrm{~nm}$. Background fluorescence at each wavelength was measured in the same tissue prior to dye loading and subtracted from the respective measurements before calculation of the fluorescence ratio $F 500 / F 440$. The linear relationship between this quantity and $\mathrm{pH}_{\mathrm{i}}$ was determined in each tissue after the experimental protocol by membrane permeabilization with nigericin $\left(2 \times 10^{-5} \mathrm{M}\right)$ and exposure to several high $\mathrm{K}^{+}$ (140 mM) solutions of varying $\mathrm{pH}[19,20]$.

Measurements of $\left[\mathrm{Ca}^{2+}\right]_{\mathrm{i}}$ were performed in a similar way in separate tissues loaded with fura-2 [21]. Details of this procedure have been described elsewhere [18]. In brief, tissues were loaded with fura-2 by incubation for $5 \mathrm{~h}$ at room temperature with a $20 \mu \mathrm{M}$ solution of the acetoxymethyl ester form of the dye (fura-2-AM), dispersed with $0.02 \%$ Cremophore EL in physiological salt solution. Background fluorescence was measured in a separate, adjacent strip from the same trachea incubated similarly but without fura-2-AM. Fluorescence at $510 \mathrm{~nm}$ was measured during alternating excitation at $340 \mathrm{~nm}$ or $380 \mathrm{~nm}$, the respective background measurements were subtracted and the ratio $F 340 / F 380$ was calculated at $20 \mathrm{~s}$ intervals as an index of $\left[\mathrm{Ca}^{2+}\right]_{i}$.

After the experimental protocol, ionomycin $\left(10^{-5} \mathrm{M}\right)$ was added to equilibrate intracellular with extracellular $\mathrm{Ca}^{2+}$ and fluorescence measurements were made in the presence of low and high $\mathrm{Ca}^{2+}$ by: 1) replacing the bath solution with a $\mathrm{Ca}^{2+}$-free calibrating solution ( $1 \mathrm{mM}$ ethylene glycol-bis ( $\beta$-aminoethyl ether)- $N, N$-tetraacetic acid (EGTA), and 2) adding $5 \mathrm{mM} \mathrm{Ca}{ }^{2+}$. $\left[\mathrm{Ca}^{2+}\right]_{\mathrm{i}}$ was then calculated at each time point of the protocol using the equation of GrynkiEwicz et al. [21] and a fura-2-Ca ${ }^{2+}$ dissociation constant of $386 \mathrm{nM}$ [22].

\section{Drugs}

Carbachol, NDGA, phenidone and isoproterenol were dissolved in Krebs-Henseleit solution. BCECF-AM was purchased from Sigma (St Louis, MO, USA) and fura-2AM from Texas Fluorescence Labs (Austin, TX, USA). Stock solutions of nifedipine $\left(10^{-2} \mathrm{M}\right)$ and indomethacin $\left(10^{-2} \mathrm{M}\right)$ were dissolved in $70 \%$ ethanol and diluted with Krebs-Henseleit solution. Concentrations described in the text refer to final organ bath concentrations.

\section{Statistical analysis}

Responses to carbachol and responses to hypocapnia within bronchial rings were compared using analysis of variance (ANOVA) for repeated measures and Duncan's multiple range test. A p-value ð0.05 was used to indicate statistical significance. Data are expressed as mean \pm SEM. 


\section{Results}

In three preliminary experiments with bronchial rings not precontracted with carbachol, the gas supplied to the organ chambers was changed from $95 \% \mathrm{O}_{2} / 5 \% \mathrm{CO}_{2}$ to $100 \% \mathrm{O}_{2}$. No changes in tension were recorded in these rings (data not shown). In all subsequent experiments, the tissues were first contracted with carbachol. Hypocapnic challenges $\left(5 \% \mathrm{CO}_{2} / 95 \% \mathrm{O}_{2}\right.$ to $\left.100 \% \mathrm{O}_{2}\right)$ of bronchial rings contracted with $1 \mu \mathrm{M}$ carbachol or tracheal strips contracted with $0.1 \mu \mathrm{M}$ carbachol resulted in reproducible and reversible increases in tension in both tissues (fig. 1). To confirm that these contractions were not dependent on hyperoxic conditions, similar studies were performed using $5 \% \mathrm{CO}_{2}$ in air $\left(\sim 20 \% \mathrm{O}_{2}\right)$ and air $\left(\sim 21 \% \mathrm{O}_{2}\right)$. Qualitatively similar responses were observed.

Repeated challenges of bronchial rings with hypocapnia in air were reproducible (fig. 2). Neither the carbachol-induced tension immediately before hypocapniainduced contraction nor the increase in tension during hypocapnia were significantly different for the first or second exposures $(\mathrm{n}=8, \mathrm{p}=0.23)$. Responses to hypocapnia, expressed either as the absolute change in tension during hypocapnia ( $3.8 \pm 0.7$ versus $4.0 \pm 0.7 \mathrm{mN}$, respectively) or as the per cent increase above carbachol-induced tension ( $87 \pm 14 \%$ versus $87 \pm 9 \%$, respectively) were similar during the first and second challenges (fig. 2).

In normocapnic solution (external $\mathrm{pH}\left(\mathrm{pH}_{\mathrm{e}}\right)=7.39 \pm$ $0.05)$, tracheal strips had $\mathrm{pH}_{\mathrm{i}}=7.23 \pm 0.04(\mathrm{n}=4)$. Carbachol $(0.1 \mu \mathrm{M})$ increased tension without altering $\mathrm{pH}_{\mathrm{i}}$ or $\mathrm{pH}_{\mathrm{e}}$ (fig. 3). A transient decrease in $\mathrm{PH}_{i}$ has been reported at a higher carbachol concentration but not at the $\sim$ ED50 concentration used in this study [19]. During hypocapnia $\left(100 \% \mathrm{O}_{2}\right)$, tension, $\mathrm{pH}_{\mathrm{i}}$ and $\mathrm{pH}_{\mathrm{e}}$ increased approximately in parallel and were restored to baseline after the return to the control gas.

Baseline $\left[\mathrm{Ca}^{2+}\right]_{\mathrm{i}}$ in other tracheal strips was $260 \pm 50 \mathrm{nM}$ $(\mathrm{n}=5)$. Carbachol produced simultaneous increases in tension and $\left[\mathrm{Ca}^{2+}\right]_{i}$ in the presence of $95 \% \mathrm{O}_{2} / 5 \% \mathrm{CO}_{2}$ (fig. 4). Switching to $0 \% \mathrm{CO}_{2}$ resulted in further increases in both tension and $\left[\mathrm{Ca}_{2+}\right]_{\mathrm{i}}$, which reversed after returning to gas containing $5 \% \mathrm{CO}_{2}$. The time courses of changes in tension and $\left[\mathrm{Ca}^{2+}\right]_{i}$ during hypocapnia were similar. However,
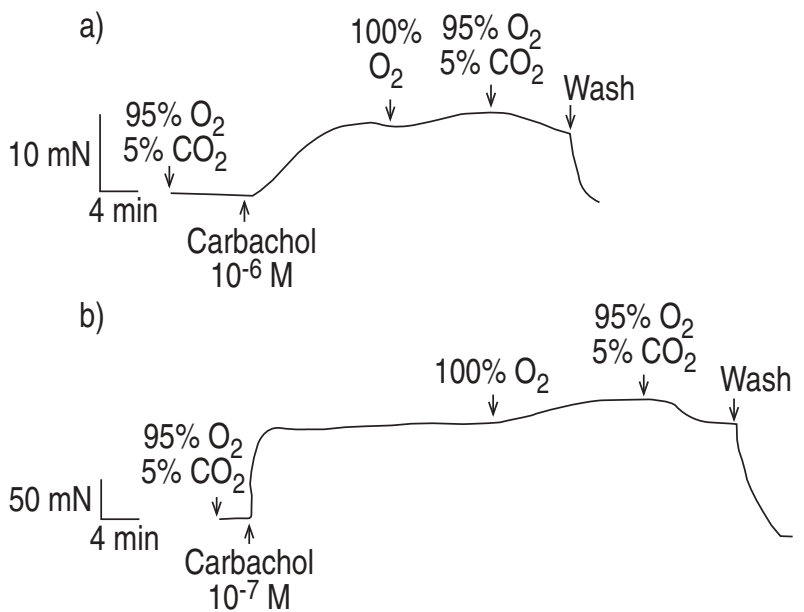

Fig. 1. - Typical traces showing the effects of carbachol and hypocapnia $\left(100 \% \mathrm{O}_{2}\right)$ in porcine a) bronchial rings and b) tracheal smooth muscle strips.
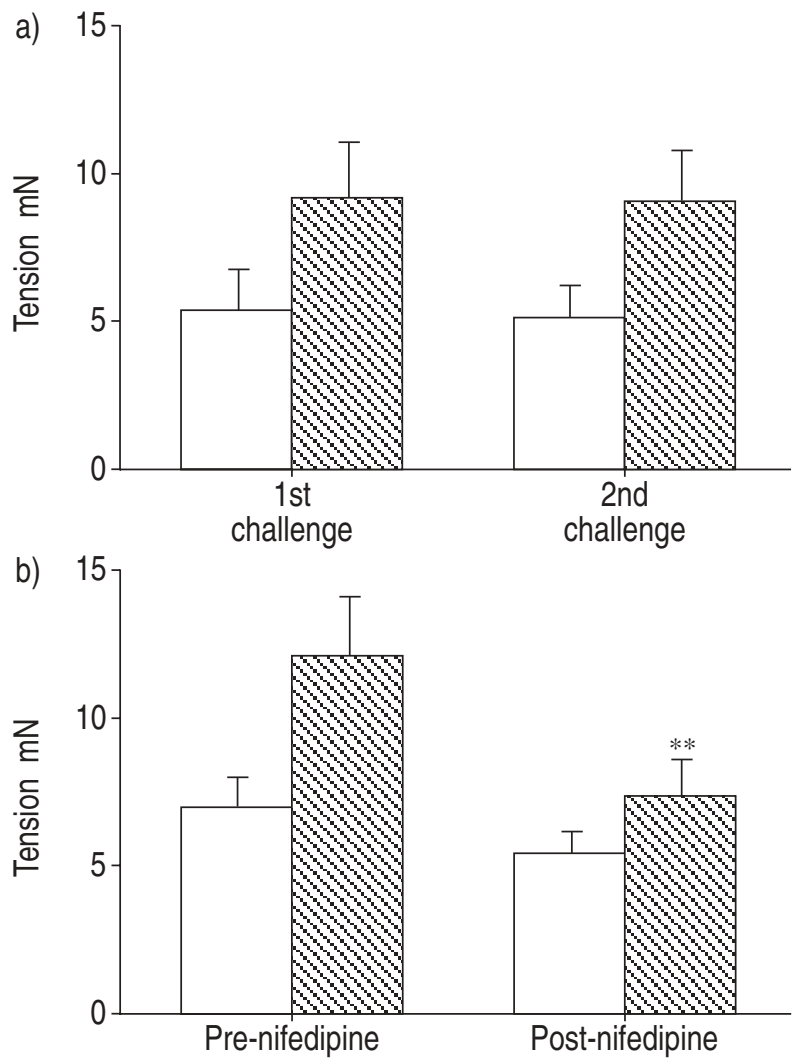

Fig. 2. - Contractile responses to hypocapnia $\left(21 \% \mathrm{O}_{2}\right)$ in porcine bronchi showing a) reproducibility of consecutive responses in the same ring $(n=8)$ and $b)$ inhibition by $0.3 \mu \mathrm{M}$ nifedipine $(n=7)$. **: $\mathrm{p}<0.01$ compared with pre-nifedipine contractile response. $\square$ : baseline; $\mathbf{3}$ : hypocapnia.

possible dissociation of these effects on a faster time scale could have been missed in this study. Similar in-creases in tension and $\left[\mathrm{Ca}^{2+}\right]_{\mathrm{i}}$ were observed in tracheal smooth muscle strips precontracted with $\mathrm{KCl}$ rather than with carbachol (fig. 5).

Pharmacological studies employed repeated hypocapnic challenges with addition of a single drug between the first and second challenges. Indomethacin, phenidone, and NDGA did not significantly alter either carbacholinduced tone or changes in tension during hypocapnia in bronchial rings (table 1). Carbachol-induced tension before hypocapnia in the presence of nifedipine $(3 \mu \mathrm{M})$ was not significantly different from that in the absence of nifedipine in bronchial rings (fig. 2). However, responses to hypo-capnia, measured either as the change in tension $(2.1 \pm 0.6$ versus $5.1 \pm 1.1 \mathrm{mN}$, respectively) or as the per cent incre-ase in active tension $(39 \pm 9 \%$ versus $75 \pm 11 \%$, respectively), were significantly smaller $(n=7, p<0.01)$ in the presence than in the absence of nifedipine. Ethanol, the vehicle for nifedipine and indomethacin, did not significantly affect responses $(n=7, p=0.92)$. Carbacholinduced tension $(5.8 \pm 1.5 \mathrm{mN}$ pre-ethanol versus $6.1 \pm 1.7$ $\mathrm{mN}$ post-ethanol, Ns) and responses to hypocapnia $(3.2 \pm 0.6 \mathrm{mN}$ pre-ethanol versus $3.2 \pm 0.8 \mathrm{mN}$ post-ethanol, NS) were similar.

Nifedipine had similar effects on responses to hypocapnia in tracheal strips (fig. 6) as in bronchial rings (fig. 2). Consecutive challenges with hypocapnia in the absence of nifedipine resulted in reproducible contractile respon- 

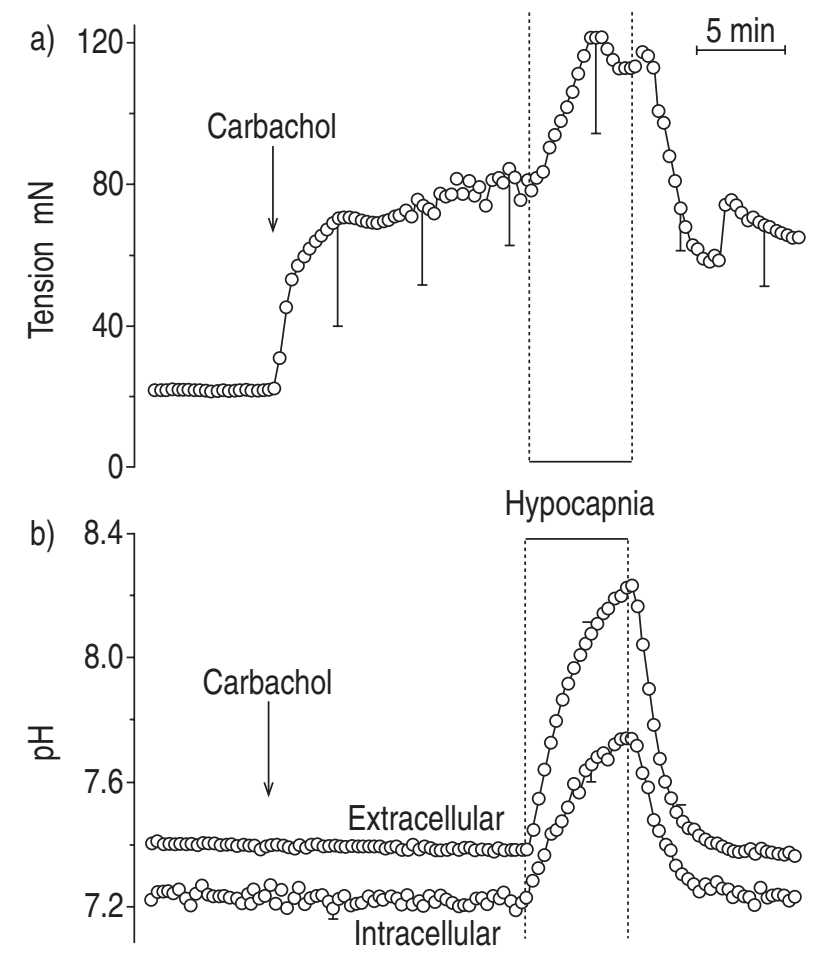

Fig. 3. - a) Tension and b) extracellular and intracellular $\mathrm{pH}$ of porcine tracheal smooth muscle strips during contraction with carbachol $\left(10^{-7}\right.$ M) and exposure to hypocapnic gas $\left(100 \% \mathrm{O}_{2}\right)$. Bars denote SEM $(n=4)$.

ses in this tissue (fig. 6). Nifedipine $(0.1 \mu \mathrm{M})$, added to the tissue baths between the first and second challenges, markedly attenuated responses to hypocapnia $(7.7 \pm 1.0$ $\mathrm{mN}$ versus $1.8 \pm 0.9 \mathrm{mN}$ before and after nifedipine, $\mathrm{n}=3$, $\mathrm{p}<0.05)$. In tracheal strips, nifedipine also attenuated carbachol-induced tension by $48 \pm 11 \%(\mathrm{n}=3, \mathrm{p}<0.05)$. To eliminate the possibility that reduced carbachol-induced tension caused the attenuation of responses to hypocapnia in the presence of nifedipine, isoproterenol was used to decrease the carbachol-induced tension in separate tissues. Neither carbachol-induced tension $(43.6 \pm 4.3 \mathrm{mN}$ ver-sus $45.2 \pm 5.5 \mathrm{mN}, \mathrm{n}=3$, Ns) nor responses to hypocapnia $(7.3 \pm 0.6 \mathrm{mN}$ versus $7.7 \pm 1.2 \mathrm{mN}$, Ns) differed significantly between the first and second challenges in the absence of isoproterenol (fig. 7). Isoproterenol, added to the tissue bath between the first and second challenges, significantly attenuated carbachol-induced tension by $24 \pm 3 \%(n=3, p<0.05)$, but did not diminish responses to hypocapnia (fig. 7).

\section{Discussion}

Low $\mathrm{CO}_{2}$ concentrations increase the airway resistance of humans [1-4] and other animals [5-10] in vivo. Hypocapnia might act through neural reflexes, by increasing blood vessel calibre, provoking mediator release or directly contracting airway smooth muscle. The in vitro experiments of this study demonstrated hypocapnia-induced contraction in isolated porcine bronchial rings and tracheal smooth muscle strips precontracted with either carbachol or $\mathrm{KCl}$. Indomethacin, phenidone, and NDGA did not alter the hypocapnia-induced contraction (table 1), in-

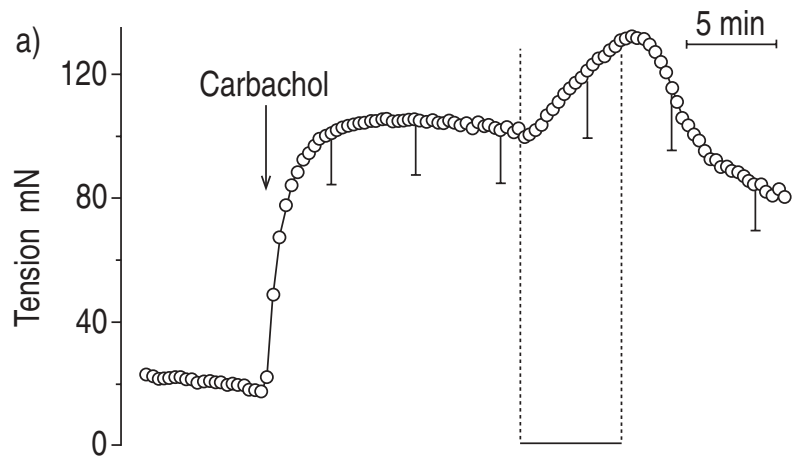

Hypocapnia

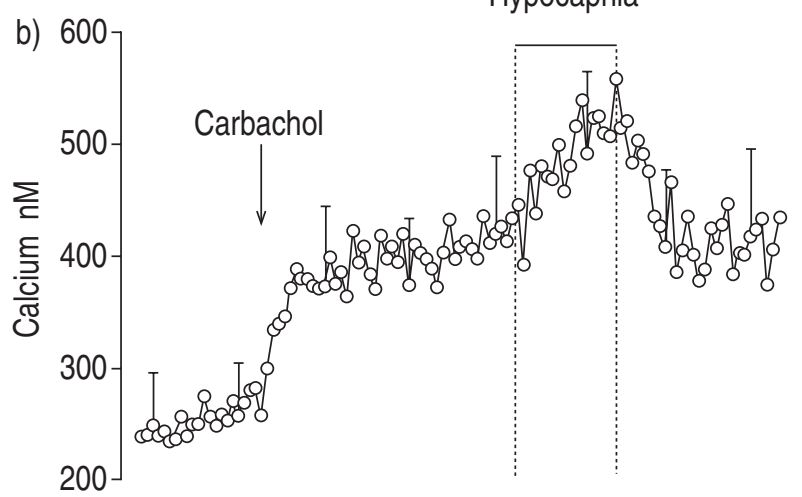

Fig. 4. - a) Tension and b) intracellular free $\mathrm{Ca}^{2+}$ concentration of porcine tracheal smooth muscle strips during contraction with carbachol $\left(10^{-7} \mathrm{M}\right)$ and exposure to hypocapnic gas $\left(100 \% \mathrm{O}_{2}\right)$. Bars denote SEM $(n=4)$.

dicating that paracrine effects mediated through cyclooxygenase products or leukotrienes are not important in the in vitro responses. The role of histamine in this response was not tested because histamine does not cause a sustained contraction in this tissue. These data suggest that hypocapnia has a direct contractile effect on airway smooth muscle cells.

The effects of $\mathrm{CO}_{2}$ on airway muscle itself can explain reported effects of hypocapnia on the lung peripheral airways in vivo. For example, in canine peripheral airways that lack significant vagal innervation, hypocapnia produced a marked bronchoconstriction which was not attenuated by atropine [6]. Furthermore, hypocapnia induced by pulmonary arterial occlusion in dogs increased whole lung resistance and decreased compliance, but vagotomy attenuated only the increase in resistance [5]. Because compliance measurements primarily reflect characteristics of the peripheral airways, these findings indicate that hypocapnia-induced constriction of peripheral airways does not involve vagal reflexes. However, hypocapnic responses of central airways appear to involve an additional contribution of cholinergic reflexes $[3,5]$. Although the present study involved large airways, the qualitatively similar hypocapnic responses that were observed in smooth muscle preparations from tracheae and bronchi and the consistency between results from the present study and those from previous in vivo studies of canine peripheral airways argue against large regional variations in the cellular mechanisms involved.

Responses to hypocapnia showed significant variability between individual tissues, between trachea (figs. 1, 3-7) 

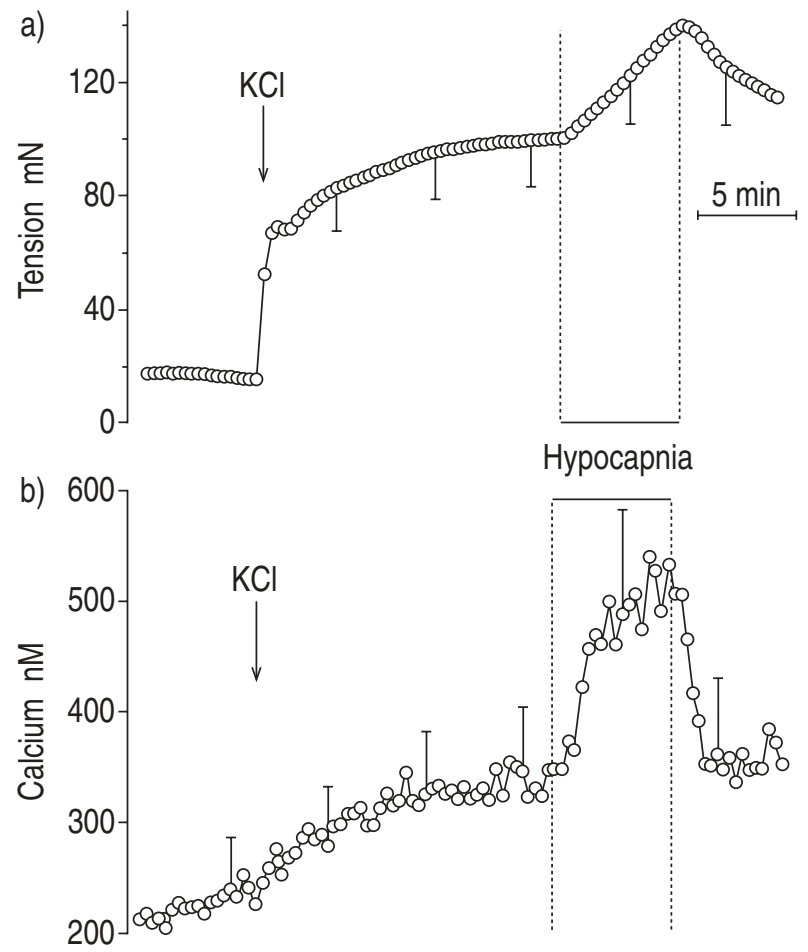

Fig. 5. - a) Tension and b) intracellular free $\mathrm{Ca}^{2+}$ concentration of porcine tracheal smooth muscle strips during contraction with $\mathrm{KCl}(40 \mathrm{mM})$ and exposure to hypocapnic gas $\left(100 \% \mathrm{O}_{2}\right)$. Bars denote SEM $(n=4)$.

and bronchus (figs. 1,2), and between conditions of $100 \%$ $\mathrm{O}_{2}$ (fig. 1) and $21 \% \mathrm{O}_{2}$ (fig. 2, table 1). Proportional increases in tension tended to be greater in tracheal strips than in bronchial rings, and in tracheal strips used for fluorometric experiments than in tracheal strips used in tissue bath experiments, probably because of differences in tissue dissection and the amount of connective tissue present. Proportional increases in tension also tended to be greater under conditions of $21 \% \mathrm{O}_{2}$, perhaps because carbachol-induced tension tended to be lower in this situation. Because of these sources of variability, differences between control and test tissues from the same animals were only evaluated under comparable conditions.

To investigate the cellular mechanisms involved in airway smooth muscle responses to hypocapnia, $\mathrm{pH}_{\mathrm{i}}$ and $\left[\mathrm{Ca}^{2+}\right]_{\mathrm{i}}$ were measured in tracheal smooth muscle strips using the fluorescent dyes BCECF and fura-2, respectively. Changing from $5 \%$ to $0 \% \mathrm{CO}_{2}$ produced a 0.7 unit alkaline shift in bath $\mathrm{pH}$, a parallel 0.4 unit increase in $\mathrm{pH}_{\mathrm{i}}$ (fig. 3), and a consistent increase in $\left[\mathrm{Ca}^{2+}\right]_{\mathrm{i}}$ (fig. 4). Similar changes in $\mathrm{pH}_{\mathrm{i}}$ have been seen in vascular smooth muscle [23]. Because the increment in $\left[\mathrm{Ca}^{2+}\right]_{\mathrm{i}}$ had a time course

Table 1. - Responses to hypocapnia in bronchial rings before and after pharmacological intervention

\begin{tabular}{|c|c|c|c|c|}
\hline & \multicolumn{2}{|c|}{ Tension $\mathrm{mN}^{*}$} & \multirow[b]{2}{*}{$\mathrm{p}$-value } & \multirow[b]{2}{*}{$\mathrm{n}$} \\
\hline & Before & After & & \\
\hline Indomethacin $(5 \mu \mathrm{M})$ & $3.7 \pm 0.5$ & $4.5 \pm 0.7$ & 0.07 & 6 \\
\hline Phenidone $(10 \mu \mathrm{M})$ & $4.2 \pm 0.6$ & $4.3 \pm 0.5$ & 0.81 & 6 \\
\hline NDGA $(10 \mu \mathrm{M})$ & $4.1 \pm 0.3$ & $4.4 \pm 0.5$ & 0.66 & 6 \\
\hline
\end{tabular}

*: active tension above carbachol-induced baseline tension. Data are expressed as means \pm SEM. NDGA: nordihydroguaiaretic acid.
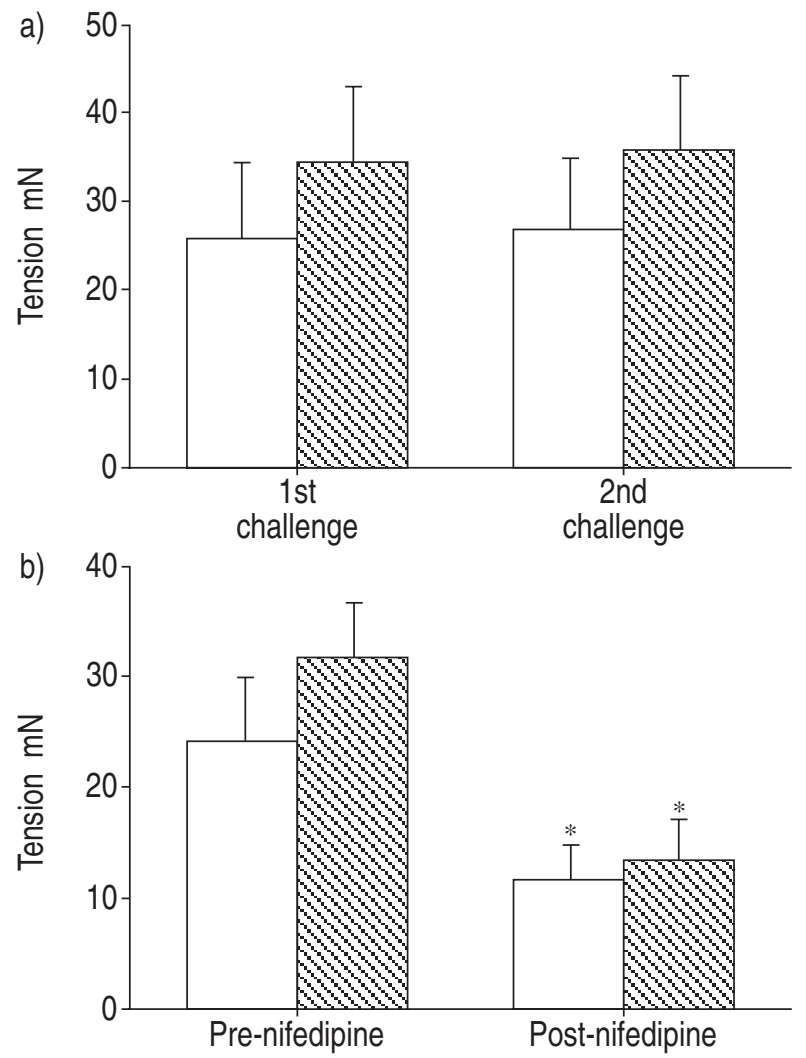

Fig. 6. - Contractile responses to hypocapnia $\left(100 \% \mathrm{O}_{2}\right)$ in porcine tracheal strips showing a) reproducibility of consecutive responses in the same strip $(n=3)$ and b) inhibition by $0.1 \mu \mathrm{M}$ nifedipine $(n=3)$. *: $\mathrm{p}<0.05$ compared with pre-nifedipine contractile response. $\square$ : baseline; 8 : hypocapnia.

similar to those of tension, $\mathrm{pH}_{\mathrm{e}}$, and $\mathrm{pH}_{\mathrm{i}}($ figs 5,6$)$ and was comparable in magnitude to that induced by $10^{-7} \mathrm{M}$ carbachol, it is likely that a pH-dependent increase in $\left[\mathrm{Ca}^{2+}\right]_{\mathrm{i}}$ is primarily responsible for the increase in active tension during hypocapnia. Similar increases in $\left[\mathrm{Ca}^{2+}\right]_{\mathrm{i}}$ were seen in $\mathrm{KCl}$-contracted smooth muscle strips (fig. 5), indicating that the effect of hypocapnia is not simple potentiation of a cholinergic stimulus. The data do not support a prominent role for sensitization of the contractile apparatus to calcium by changes in $\mathrm{pH}$, consistent with findings in rat vascular smooth muscle [24] and in guinea-pig taenia coli [24]. Tracheal smooth muscle appears to differ in this regard from porcine coronary artery, in which increases in $\mathrm{pH}_{\mathrm{i}}$ caused enhanced contractile sensitivity to $\left[\mathrm{Ca}^{2+}\right]_{\mathrm{i}}[25]$. Calcium sensitivity was decreased with increased $\mathrm{pH}_{\mathrm{i}}$ in the rat portal vein and human umbilical artery [26].

Several mechanisms could contribute to hypocapnia-induced increases in $\left[\mathrm{Ca}^{2+}\right]_{\mathrm{i}}$ of airway smooth muscle cells, including release from intracellular stores of calcium and enhanced entry of calcium due to membrane depolarization or to direct effects on voltage-dependent or receptoroperated calcium channels. Since L-type channels may play a role in $\mathrm{Ca}^{2+}$ influx in airway smooth muscle during agonist stimulation $[27,28]$, the involvement of these channels in hypocapnia-induced contraction was tested using the $\mathrm{Ca}^{2+}$ channel antagonist nifedipine at concentrations (3 $\mu \mathrm{M}$ or $0.1 \mu \mathrm{M})$ sufficient to relax $\mathrm{KCl}$-contracted bronchial rings or tracheal strips [27]. Nifedipine markedly reduced responses to hypocapnia (figs 2,6 ). These data 

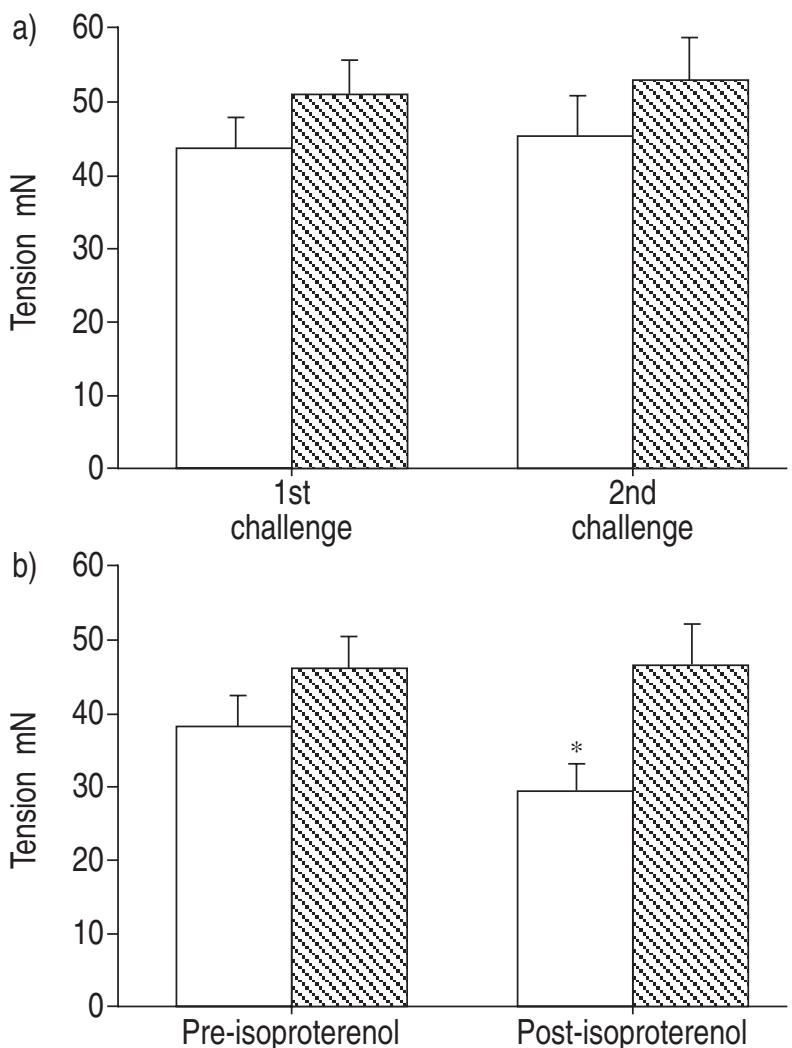

Fig. 7. - Contractile responses to hypocapnia $\left(100 \% \mathrm{O}_{2}\right)$ in porcine tracheal strips showing a) reproducibility of consecutive responses in the same strip ( $n=3)$ and $b)$ inhibition of carbachol-induced tension, but not responses to hypocapnia, by $0.1 \mu \mathrm{M}$ isoproterenol (n=3). $\square$ : baseline; $\mathbf{3}$ : hypocapnia.

indicate the involvement of L-type $\mathrm{Ca}^{2+}$ channels in the hypocapnic response and parallel in vivo results that implicate $\mathrm{Ca}^{2+}$ entry through voltage-dependent $\mathrm{Ca}^{2+}$ channels in hypocapnia-induced airway constriction $[6,7]$.

In tracheal strips, but not in bronchial rings, nifedipine also attenuated carbachol-induced tension. This antagonism of contraction does not explain the attenuation by nifedipine of responses to hypocapnia in tracheal smooth muscle, since isoproterenol also reduced carbachol-induced tension but without decreasing responses to hypocapnia (fig. 7). The relative insensitivity of carbachol-contracted bronchial rings to nifedipine may reflect the importance of dihydropyridine-insensitive pathways for $\mathrm{Ca}^{2+}$ entry during cholinergic stimulation of lower airway smooth muscle [27]. Despite this apparent regional variation in the mechanisms for agonist-enhanced $\mathrm{Ca}^{2+}$ entry, low $\mathrm{PCO}_{2}{ }^{-}$ induced increases in $\mathrm{Ca}^{2+}$ entry appear to involve primarily L-type $\mathrm{Ca}^{2+}$ channels in the trachea and bronchus, since hypocapnia-induced increases in force were inhibited by nifedipine in both airway smooth muscle preparations.

Responses to hypocapnia are likely to depend on intracellular concentrations of $\mathrm{H}^{+}$ions and prolonged decreases in extracellular $\mathrm{CO}_{2}$ concentration have previously been shown to increase $\mathrm{pH}_{\mathrm{i}}$ in airway muscle [29]. Direct effects of $\mathrm{pH}$ on L-type voltage-dependent $\mathrm{Ca}^{2+}$ channels have been demonstrated in a variety of smooth muscle cells $[13,30-32]$ and $\mathrm{Ca}^{2+}$ entry into airway smooth muscle is $\mathrm{pH}$ dependent [33]. The present data demonstrate changes in $\mathrm{pH}_{\mathrm{i}}$ and $\mathrm{pH}_{\mathrm{e}}$ with time courses similar to those of changes in $\left[\mathrm{Ca}^{2+}\right]_{\mathrm{i}}$ and tension (figs. 3,4 ) but cannot distinguish between the effects of intracellular and extracellular $\mathrm{pH}$. Nevertheless, patch-clamp studies in the authors' laboratory have directly demonstrated enhancement of $\mathrm{Ca}^{2+}$ currents through voltage-dependent $\mathrm{Ca}^{2+}$ channels of tracheal smooth muscle cells with increases of intracellular but not extracellular $\mathrm{pH}$ [13]. Thus, it is suggested that hypocapnia constricts airway smooth muscle via a direct effect of intracellular alkalosis on $\mathrm{Ca}^{2+}$ influx through L-type $\mathrm{Ca}^{2+}$ channels. Interestingly, the patch-clamp data showed that increases in $\mathrm{pH}_{\mathrm{i}}$ enhanced the magnitude of depolarization-induced currents but did not alter the voltage dependence of channel activation [13]. This behaviour is entirely consistent with the present demonstration that hypocapnia had little effect in resting muscle, but did increase the magnitude of the contraction in carbachol-treated tissues in which $\mathrm{Ca}^{2+}$ channels are presumably opened by depolarization.

Indirect activation of voltage-dependent $\mathrm{Ca}^{2+}$ channels could also occur if alkalosis depolarized the smooth muscle cell membranes. Potassium currents of vascular smooth muscle cells were reduced with increases in $\mathrm{pH}_{\mathrm{i}}$ [34], consistent with this mechanism. However, $\mathrm{pH}$ had no significant effect on potassium currents in myometrium [30] and the prominent $\mathrm{Ca}^{2+}$-activated $\mathrm{K}^{+}$channels of airway smooth muscle are activated rather than inhibited by increased $\mathrm{pH}$ [35]. Furthermore, in this study, hypocapnia produced contraction in depolarized smooth muscle (fig. 5). This argues strongly against an important role for $\mathrm{K}^{+}$ channel inhibition in the hypocapnia response, since membrane potential is resistant to change by alterations in $\mathrm{K}^{+}$ channel activity in the presence of elevated extracellular $\mathrm{K}^{+}$. Voltage-dependent $\mathrm{Ca}^{2+}$ channels are also activated by the depletion of intracellular $\mathrm{Ca}^{2+}$ stores through a poorly understood mechanism [36]. Hence, the release of $\mathrm{Ca}^{2+}$ from the sarcoplasmic reticulum by increased $\mathrm{pH}_{\mathrm{i}}$ might also contribute to nifedipine-sensitive hypocapnia-induced contraction. The present data do not directly address this possibility. However, hypocapnia stimulates phosphatidylinositol turnover in rat tracheal muscle, which would presumably stimulate the release of calcium from intracellular stores [37].

In summary, in vitro models were developed to investigate the mechanism of hypocapnia-induced airway constriction. Tension induced by carbachol in bronchial or tracheal smooth muscle preparations was enhanced by hypocapnia. Increases in tracheal smooth muscle tension were accompanied by increases in intracellular $\mathrm{pH}$ and the intracellular free calcium concentration. Cyclo-oxygenase and lipoxygenase inhibition did not prevent the tension response, but pretreatment with nifedipine diminished the hypocapnia-induced contraction. These studies indicate that hypocapnia affects airway smooth muscle directly and that the enhancement of calcium entry through voltage-dependent calcium channels, possibly via increased intracellular $\mathrm{pH}$, plays an important role in this response.

\section{References}

1. Nielsen TM, Pederson OF. The effect of $\mathrm{CO}_{2}$ on peripheral airways. Acta Physiol Scand 1976; 98: 192-199.

2. Newhouse MT, Becklake RR, Macklem PT, McGregor $\mathrm{M}$. Effect of alterations in end-tidal $\mathrm{CO}_{2}$ tension on flow resistance. J Appl Physiol 1964; 19: 745-749. 
3. Sterling GM. The mechanism of bronchoconstriction due to hypocapnia in man. Clin Sci 1968; 34: 277-285.

4. van der Elshout FJJ, van Herwaarden CLA, Folgering HTM. Effects of hypercapnia and hypocapnia on respiratory resistance. J Appl Physiol 1964; 19: 745-749.

5. Ingram RH Jr. Effects of airway versus arterial $\mathrm{CO}_{2}$ changes on lung mechanics in dogs. J Appl Physiol 1975; 38 : 603-607.

6. Kolbe J, Kleeberger SR, Menkes HA, Spannhake EW. Hypocapnia-induced constriction of the canine peripheral airways exhibits tachyphylaxis. J Appl Physiol 1987; 63: 497-504.

7. Lindeman KS, Hirshman CA, Freed AN. Calcium channel blockers modulate airway constriction in the canine lung periphery. J Appl Physiol 1991; 70: 624-630.

8. Severinghous JW, Swenson EW, Finley TN, Lategola MT, Williams J. Unilateral hypoventilation produced in dogs by occluding one pulmonary artery. J Appl Physiol 1961; 16: 53-60.

9. Traystman RJ, Batra GK, Menkes HA. Local regulation of collateral ventilation by oxygen and carbon dioxide. $J$ Appl Physiol 1976; 40: 819-823.

10. Traystman RJ, Terry PB, Menkas HA. Carbon dioxide: a major determinant of collateral ventilation. J Appl Physiol 1978; 45: 69-74.

11. Freed AN, Munakata M. Dry air-induced bronchoconstriction: a role for voltage-sensitive calcium channels. Am Rev Respir Dis 1989; 140: 344-349.

12. Gerthoffer WT. Regulation of the contractile element of airway smooth muscle. Am J Physiol (Lung Cell Mol Physiol) 1991; 261: L15-L28.

13. Yamakage M, Lindeman KS, Hirshman CA, Croxton TL. Intracellular $\mathrm{pH}$ regulates voltage-dependent $\mathrm{Ca}^{2+}$ channels in porcine tracheal smooth muscle cells. Am J Physiol (Lung Cell Mol Physiol) 1995; 268: L642-L646.

14. Sayiner A, Warner DO, Lorenz RR, Katusic ZS, Rehder $\mathrm{K}$. $\mathrm{CO}_{2}$ affects canine airway smooth muscle tone independently from epithelium-derived factors. FASEB $J$ 1990; 4: A1092.

15. Lindeman KS, Fernandes LB, Croxton TL, Hirshman CA. Role of potassium channels in hypoxic relaxation of porcine bronchi in vitro. Am J Physiol (Lung Cell Mol Physiol) 1994; 266: L232-L237.

16. Lindeman KS, Baker SG, Hirshman CA. Interaction between halothane and the nonadrenergic, noncholinergic inhibitory system in porcine trachealis muscle. Anesthesiology 1994; 81: 641-648.

17. Fernandes LB, Stuart-Smith K, Croxton TL, Hirshman CA. Role of $\mathrm{Ca}^{2+}$ entry in the modulation of airway tone by hypoxia. Am J Physiol (Lung Cell Mol Physiol) 1993; 264: L284-L289.

18. Kumasaka D, Lindeman KS, Clancy J, Lande B, Croxton TL, Hirshman CA. $\mathrm{MgSO}_{4}$ relaxes porcine airway smooth muscle by reducing $\mathrm{Ca}^{2+}$ entry. Am J Physiol (Lung Cell Mol Physiol) 1996; 270: L469-L474.

19. Croxton TL, Lande B, Hirshman CA. Role of intracellular $\mathrm{pH}$ in relaxation of porcine tracheal smooth muscle by respiratory gases. Am J Physiol (Lung Cell Mol Physiol) 1995; 268: L207-L213.

20. Challiet JR, Boron WF. Intracellular calibration of a pHsensitive dye in isolated perfused salamander proximal tubules. J Gen Physiol 1985; 86: 765-794.
21. Grynkiewicz G, Poenie M, Tsien RY. A new generation of $\mathrm{Ca}^{2+}$ indicators with greatly improved fluorescence properties. J Biol Chem 1985; 260: 3440-3450.

22. Kajita J, Yamaguchi H. Calcium mobilization by muscarinic cholinergic stimulation in bovine single airway smooth muscle. Am J Physiol (Lung Cell Mol Physiol) 1993; 264: L496-L503.

23. Aickin CC. Regulation of intracellular $\mathrm{pH}$ in smooth muscle cells of the guinea-pig femoral artery. J Physiol Lond 1994; 479: 331-340.

24. Austin C, Wray S. The effects of extracellular $\mathrm{pH}$ and calcium change on force and intracellular calcium in rat vascular smooth muscle. J Physiol Lond 1995; 488: 281291.

25. Nagsetty R, Paul RJ. Effects of $\mathrm{pH}_{\mathrm{i}}$ on isometric force and $\left[\mathrm{Ca}^{2+}\right]_{i}$ in porcine coronary artery smooth muscle. Circ Res 1994; 78: 990-998.

26. Crichton CA, Templeton AG, Smith GL. Effect of altered bathing $\mathrm{pH}$ on calcium activated force in alpha toxin permeabilized rat portal vein and human umbilical artery. Cardiovasc Res 1994; 28: 1378-1384.

27. Croxton TL, Fleming C, Hirshman CA. Expression of dihydropyridine resistance differs in porcine bronchial and tracheal smooth muscle. Am J Physiol (Lung Cell Mol Physiol) 1994; 267: L106-L112.

28. Fleischmann BK, Murray RK, Kotlikoff MI. Voltage window for sustained elevation of cytosolic calcium in smooth muscle cells. Proc Natl Acad Sci USA 1994; 91: 11914-11918.

29. Stephens NL, Mitchell RW. Effect of respiratory acidosis and activity on airway smooth muscle intracellular $\mathrm{pH}$. $J$ Appl Physiol 1977; 42: 408-412.

30. Shmigol AV, Smith RD, Taggart MJ, Wray S, Eisner DA. Changes of $\mathrm{pH}$ affect calcium currents but not outward potassium currents in rat myometrial cells. Pflugers Arch 1995; 431: 135-137.

31. Iino S, Hayashi H, Saito H, Tokuno H, Tomita T. Effects of intracellular $\mathrm{pH}$ on calcium currents and intracellular calcium ions in the smooth muscle of rabbit portal vein. Exp Physiol 1994; 79: 669-680.

32. Horie $\mathrm{S}$, Yano $\mathrm{S}$, Watanabe K. Intracellular alkalinization by $\mathrm{NH}_{4} \mathrm{Cl}$ increases cytosolic $\mathrm{Ca}^{2+}$ level and tension in the rat aortic smooth muscle. Life Sci 1995; 56: 1835-1843.

33. Twort CHC, Cameron IR. Effects of $\mathrm{PCO}_{2}, \mathrm{pH}$ and extracellular calcium on contraction of airway smooth muscle in rats. Respir Physiol 1986; 66: 259-267.

34. Bennet P, Rusch NJ, Harder DR. Characterization of an outward $\mathrm{K}^{+}$current in freshly dispersed cerebral arterial muscle cells. Pflugers Arch 1991; 418: 292-296.

35. Kume H, Tagalo K, Satake T, Tokuno H, Tomita T. Effects of intracellular $\mathrm{pH}$ on calcium-activated potassium channels in rabbit tracheal smooth muscle. J Physiol (Lond) 1990; 424: 445-457.

36. Bourreau JP, Kway CY, Daniel EE. Distinct pathways to refill $\mathrm{ACh}$-sensitive internal $\mathrm{Ca}^{2+}$ stores in canine airway smooth muscle. Am J Physiol (Cell Physiol) 1993; 265: C28-C35.

37. Shibata O, Makita T, Tsujita T, et al. Carbachol, norepinephrine, and hypocapnia stimulate phosphatidylinositol turnover in rat tracheal slices. Anesthesiology 1995; 82: 102-107. 